\title{
Team Perceptions of Choir Members
}

\author{
Duygu Piji Küçük ${ }^{1}$, Bülent Halvaşi ${ }^{1}$ \\ ${ }^{1}$ Marmara University, Turkey \\ Correspondence: Duygu Piji Küçük, Marmara University, Turkey
}

Received: February 11, 2019

Accepted: February 24, 2019 Online Published: February 26, 2019

doi:10.11114/jets.v7i3.4043

URL: https://doi.org/10.11114/jets.v7i3.4043

\begin{abstract}
The success of a choir depends on the integrity, concentration and team logic to be formed within the group under the leadership of the choir conductor. Some dimensions of team perception are considered to be important for choral success such as knowing the aims of the choir, being aware of each other's talent levels, sharing the feeling of success and failure, having trust and responsibility for the group members and the conductor, being willing to work, feeling happy and proud for being a member of the choir. In this study, it is aimed to determine the level of team perception of choir members. In addition, it has been tried to determine whether the team perceptions of choir members have made a difference according to the variables of gender, age, type of graduated school and choir experience. The research group consisted of 246 choir members who are members of Marmara University Polyphonic Choir, MEF University Choir, TRT Istanbul Youth Choir, Kocaeli University Fine Arts Faculty Music Department Choir, Croatia Mato Bucar Choir and Bosnia and Herzegovina Bugojno Choir. The data of the study were collected with Chorus Team Perception Scale and personal information form, consisting of 34 items and 5 sub-dimensions. As a result of the research, it was found that the choir members generally had a high level of team perception. The average score of the choir members in sub-dimensions of the team spirit, chorus and conductor relationship, negative emotions, responsibility and effort, emotional support and collaboration, revealed a high level of team perception. According to the gender variable, a high level of difference was found in favour of female choir members among the total scores of the team members of the choir. It was found that choir members aged 22 years and older had higher choir team perception than choir members in the 14-17 and 18-21 age groups. There was no significant difference between the total score of the team perception and the sub-dimension scores of the choir members according to the type of school they graduated and the choir experience variables.
\end{abstract}

Keywords: choir members, team perception, choir conductor, choir team perception

\section{Introduction}

Sound is the most important communication tool of man. Human voice is an instrument that allows people to talk, to interact with their environment and it can also be used as a musical instrument. This structure of the human voice takes back the interaction between choral music and the human voice up to ages. In the primitive tribes, the collective ceremonies and entertainment activities were in the form of collective singing. This showed the first formations of the traditional choral music and has come to this day (Gökçe, 2007).

Chorus music aims to create healthy relations with the musical environment and the individual by singing with the correct and clean voices in community, with musical sensitivity, to participate in the music consciously, as performers and listeners and to contribute to the cultural development by using the song language (Çevik, 1997; Apaydın, 2006).

Each of the choir members will acquire his knowledge and skills by using as many senses as possible within real life so that, he will not forget easily what he has learned, will have a sense of responsibility, will develop a sense of value, will be able to apply what he knows and will become a self-confident member who is affected by other members (Yiğit, 2001). Singing together gives the individual a very important contribution, such as gaining a habit of working together, helping others to correct their mistakes and seeing their own deficiencies, respecting others, socializing, understanding the necessity of democratic values in the society, and developing a world view in art within national and international communication (Apaydın, 2006). 
Uçan (2001), mentioned the conditions to be fulfilled to create a successful choir as, feeling the necessity to speak and sing together, being together/becoming a community, being a unity, being organized, singing and speaking as a community.

Chorus training also plays an effective role in the development of some personal characteristics. These features are; to develop self-confidence and self-discipline, to make the individual active, to pass the time away from unqualified and harmful habits, to be emotional, sensitive, programmed and sharing, to gain a sense of responsibility, to use the body language well, to embrace the traditions and customs, to keep up with the era, to develop their cultural pleasures, multi-faceted, multi-dimensional thinking and being well organized (Erol, 2013).

An important share of the achievements of choir training on the individual is related to the choir conductor. The choir conductor is the person who uses the management techniques, which are used to express the music in the best way in terms of essence and form, with the support of his/her knowledge and experience. Besides this, his/her responsibilities, sometimes exceeds the musical framework. Having a social, cultural and educational identity in the foreground, he knows the psychology of the group well and intervenes in situations where it is necessary to control the general atmosphere and communicates well. As a leader, he takes his essence from the love of music and he is the one to reinforce the feelings of friendship, cohesion, solidarity, interaction and sharing within the group (Cevik, 1999; Ersoydan and Karakelle; 2014). The individual differences in the choir are gathered together and transformed into success in the common ground, thanks to the leadership of the choir conductor. The choir conductor should closely monitor the capacities and needs of the group members, to make the group a success, and should focus on the objectives of the group. He should be aware of the individual abilities of the group members and should know each one separately. He should also be a leader who does not behave unethical and should make continuous observation (Ersoydan and Karakelle; 2014).

The success of a choir under the leadership of the choir conductor depends on the integrity, concentration and team logic to be formed within the group. In this context, the choir members' knowing the aim of the choir, to be aware of each other's talent dimensions, the perception of incomplete deficiencies, to share the feeling of success and failure, trust and responsibility against the group members and the conductor, the desire to work, the happiness and pride of being in the choir, are important in terms of choral success.

The team consists of people who have complementary skills in line with their common goals, performance goals and approaches towards each other (Katzenbach and Smith, 1998). Members in the team can produce a positive synergy with a coordinated study. As a result, the individual efforts of the team members emerge with a level of performance that is greater than the sum of the individual inputs alone. Team members share tasks according to a specific division of labour and have detailed information about their work. In this way, each team member knows the field of authority and responsibility and may exhibit appropriate behaviours (Çetin, 2009; as cited in İlhan and İnce, 2015).

Characteristics of a good team member can be expressed as, being open to learning, diagnosing and analyzing the problem, giving attention to details, influencing, using initiative, being willing to work in an authorized environment, verbal communication, planning and organization, teamwork and cooperation, technical and professional competence, stress management, education, orientation and guidance, empathy, high internal motivation (Baltaş, 2004).

The success of the teams depends on the team members' and the leader's enacting appropriate behaviors in line with common goals. The task of the leader is to increase the level of learning and morale by creating a team that has a common purpose, by using the power of mutual interaction, a strong sense of cooperation and sharing, and ultimately producing better ideas. Leaders should encourage teamwork in order to enable more people to do more useful jobs for the team, and attract individuals who have creative potential and cannot use it to achieve successful results. (Özler and Koparan, 2006; as cited in Güçlü and Okçu, 2015).

The choir can be likened to a team as a voice ensemble. It can be said that regarding choir members and the conductor, a choir that has good relations with each other, works towards the same goal, respects and trusts one another, uses appropriate working methods for useful and creative performances, forms and creates a regular working environment, owns all the important features required for a team with high performance (Sevinç, 2017).

In this study, it was aimed to determine the team perception levels of choir members. It is thought that determining the team perceptions of choir members will provide awareness about team perception, which is an important dimension for chorus success. Choir members are people who have come from different cultures and have different creation characteristics and expectations. Each of the members of the choir develops their own level and knowledge in this musical formation, both individually and through collective work. At this point, the importance of carrying the chorus members to the idea of choral team and providing integrity from this unequal structure difference emerges (Halvaşi, 2016; Çevik, 1997). It can be said that the adoption of positive communal elements such as production, sharing, 
cooperation, problem solving, friendship and love, which are thought to have a significant impact on the success of the choir, can be achieved by creating team consciousness.

It is hoped that the findings of the study will draw attention to the importance of team perception in the formation of choral culture and to shed light on the studies to be done in this area. Based on these thoughts, in this study, it was determined that the levels of team perception of choir members differ according to gender, age, type of graduated school and choir experience variables.

\section{Methodology}

In this study, relational screening model which is a type of general screening model is used. The general screening model is a research approach that aims to describe a situation that has existed in the past or the present. Relational screening model determines the presence and the degree of interchange between two and more variables (Karasar, 1995). The dependent variable of the study is the team perception of choir members. The relational screening method is used to determine whether the team perception levels of the choir members make a difference according to the variables of gender, age, type of graduated school and choir experience.

\subsection{Participants}

The research group is consisted of 246 choir members from Marmara University Polyphonic Choir, MEF University Choir, TRT Istanbul Youth Choir, Kocaeli University Fine Arts Faculty Music Department Choir, Croatia Mato Bucar Choir and Bugojno Chorus of Bosnia and Herzegovina.

The distribution of the choir members according to gender, age, type of graduated school and the choir experience variables are presented in the table below.

Table 1. Distribution of choir members according to gender, age, type of graduated school and choir experience variables

\begin{tabular}{|c|c|c|c|c|c|c|c|}
\hline & $\begin{array}{c}\text { Marmara } \\
\text { University } \\
\text { Polyphonic } \\
\text { Choir } \\
\end{array}$ & $\begin{array}{c}\text { MEF } \\
\text { University } \\
\text { Choir }\end{array}$ & $\begin{array}{c}\text { Kocaeli University Fine } \\
\text { Arts Faculty Music } \\
\text { Department Choir }\end{array}$ & $\begin{array}{c}\text { TRT } \\
\text { Istanbul } \\
\text { Youth Choir }\end{array}$ & $\begin{array}{c}\text { Croatia } \\
\text { Mato Bucar } \\
\text { Choir }\end{array}$ & $\begin{array}{l}\text { Bugojno Chorus of } \\
\text { Bosnia and } \\
\text { Herzegovina. }\end{array}$ & Total \\
\hline \multicolumn{8}{|l|}{ Gender } \\
\hline Female & 28 & 39 & 23 & 47 & 10 & 8 & 155 \\
\hline Male & 23 & 16 & 24 & 23 & 3 & 2 & 91 \\
\hline Total & 51 & 55 & 47 & 70 & 13 & 10 & 246 \\
\hline \multicolumn{8}{|l|}{ Age } \\
\hline $14-17$ & 0 & 26 & 0 & 24 & 2 & 7 & 59 \\
\hline $18-21$ & 43 & 20 & 25 & 34 & 7 & 2 & 131 \\
\hline $22+$ & 8 & 9 & 22 & 12 & 4 & 1 & 56 \\
\hline Total & 51 & 55 & 47 & 70 & 13 & 10 & 246 \\
\hline \multicolumn{8}{|l|}{ Type of school } \\
\hline Field of music & 46 & 3 & 17 & 9 & 13 & 1 & 89 \\
\hline $\begin{array}{l}\text { Not music } \\
\text { related }\end{array}$ & 5 & 52 & 30 & 61 & 0 & 9 & 157 \\
\hline Total & 51 & 55 & 47 & 70 & 13 & 10 & 246 \\
\hline \multicolumn{8}{|c|}{ Choir experience } \\
\hline $1-5$ years & 26 & 48 & 32 & 61 & 7 & 8 & 182 \\
\hline $6-10$ years & 25 & 7 & 15 & 9 & 6 & 2 & 64 \\
\hline Total & 51 & 55 & 47 & 70 & 13 & 10 & 246 \\
\hline
\end{tabular}

Table 1 shows the distribution of choir members according to gender, age, type of school, and choir experience variables. According to the gender variable, there is an accumulation of the female choir members and the choir members between the ages of 18-21. In the variable of graduated school type, it is seen that the number of choir members studied outside the music field is more intense. With regard to the chorus experience variable, it is possible to say that the majority of the choir members have choir experience between 1 and 5 years.

\subsection{Data collection}

In this study, Choir Team Perception Scale was used to determine the team perceptions of choir members. In addition, a personal information form has been created in order to collect data on the gender, age, the type of school they graduated and the choir experience they have.

\subsection{Choir Team Perception Scale (CTPS)}

Developed by Piji Küçük, the items of the Choir Team Perception Scale were prepared using the Team Perception Scale developed by Atılgan, Demirtaş, Bilgin Aksu and Silman (2010). Initially, the scale which was consisted of 54 items, is applied to 332 choir members as a pilot scheme. The result of KMO (Kaiser-Meyer-Olkin) sample aptitude test for the 
scale was found as .93. Then, Principal Component Analysis was applied as the factor analysis for the items of the scale and the factors were obtained by Varimax rotation process. As a result of the analysis, it was determined that the scale was composed of 34 items and 5 factors and the total variance explanation rate was determined as $56.36 \%$. The Cronbach alpha coefficient was found to be .93 as a result of the internal consistency analysis for the reliability of the scale. The first sub-scale "Team Spirit" contained 10 items and the calculated Cronbach's alpha coefficient was .90. The second sub-scale "Choir and Conductor Relationship" consists of 9 items and the calculated Cronbach alpha coefficient is .89. The third subscale, "Negative Emotions", contains 7 items and the Cronbach alpha coefficient is .78. The fourth sub-scale "Responsibility and Effort" consists of 4 items and the calculated Cronbach alpha coefficient is .79. The Cronbach alpha coefficient of the fifth subscale "Emotional Support and Collaboration" which is consisted of four items is .77. In terms of the total scale and the sub-scale correlation level, positive and high level significant relationships were found. The Choir Team Perception scale is a four-degree scale, scoring between 1 and 4 . Scoring is done according to the answers fully disagree ( 1 point), disagree ( 2 points), agree ( 3 points), fully agree ( 4 points). In the scale there are expressions about feelings and thoughts that must be achieved in line with the success of the choir such as; "We strive to be successful in the concerts and rehearsals", "Each of us is responsible for ourselves and other team members in our concerts and studies", "The performance anxiety we feel before the concerts is reduced with the help of the motivation, provided by the choir conductor", "We discuss the reasons for the failure during the concert and we work together to eliminate our deficiencies". The highest score that of the test is 136 and the lowest score is 34 . High scores from the Choir Team Perception Scale indicate that respondents have a high team perception.

According to the analysis of reliability results of Choir Team Perception Questionnaire applied to the research group, Cronbach alpha coefficient for all scales is .93, Cronbach alpha coefficient calculated for the subscale "Team Spirit" is .90, for the subscale "Choir and Conductor Relationship".88, for the "Negative Emotions" subscale .78, for the"Responsibility and Effort" subscale .79, and for the "Emotional Support and Collaboration" subscale .79.

\subsection{Data analysis}

Pearson Correlation Analysis was used to determine the relationship between the variables of the team mean score and the mean of the subscale scores (Punch, 2005). Independent samples t-test was used to determine the difference between the total score and subscale scores of the choir members according to gender, age, the type of school graduated and the choir experience variables. Independent samples $t$ test is performed, to determine if there is a significant difference between two unrelated sample means (Büyüköztürk, 2004). The significance level was accepted as p <.05 in all statistical analyses and the data were analyzed with SPSS 24 package program.

\section{Results and Discussion}

In this section, the results obtained from the analysis of the research are presented. Descriptive values of the choir members' team perception scores and subscale scores are presented in the table below

Table 2. Descriptive values of choir members according to team perception and subscale scores

\begin{tabular}{lccccc}
\hline Choir Team Perception General Scale and Sub-Scale Scores & $\mathbf{n}$ & Lowest & Highest & $\mathbf{x}$ & ss \\
\hline Choir Members' Team Perception Total Scores & & 77 & 136 & 114.34 & 13.64 \\
Team Spirit Subscale Total Scores & & 15 & 40 & 35.28 & 4.73 \\
Choir and Conductor Relationship Subscale Total Scores & 246 & 16 & 36 & 31.53 & 4.31 \\
Negative Emotions Subscale Total Scores & & 8 & 28 & 20.81 & 4.01 \\
Total Scores of Responsibility and Effort Sub-Scale & 6 & 16 & 13.30 & 2.18 \\
Emotional Support and Collaboration Subscale Total Scores & 5 & 16 & 13.40 & 2.23 \\
\hline
\end{tabular}

As seen in Table 2, the highest score choir members got from the Choir Team Perception Scale is 136 and the lowest score is 77 . Team perception mean score of the choir members is 114.34 . The general scale score averages of choir members indicate that they have a high level of team perception. When the averages of the choir members were taken into consideration in five subscales, it was found that the mean scores of Team Spirit (35.28), Choir and Conductor Relationship (31.53), Negative Emotions (20.81), Responsibility and Effort (13.30), Emotional Support and Collaboration (13.40) subscales make it possible to say there is a high level of team perception.

Table 3 presents the findings of the relationship between the total score averages of the choir members and the subscale scores. 
Table 3. Correlation analysis findings on the relationship between the total score averages of the choir members and the subscale scores

\begin{tabular}{|c|c|c|c|c|c|c|}
\hline & $\begin{array}{l}\text { Team } \\
\text { Spirit } \\
\text { Score }\end{array}$ & $\begin{array}{c}\text { Choir and } \\
\text { Conductor } \\
\text { Relationship } \\
\text { Score }\end{array}$ & $\begin{array}{c}\text { Negative } \\
\text { Emotions } \\
\text { Score }\end{array}$ & $\begin{array}{c}\text { Responsibility } \\
\text { and Effort } \\
\text { Score }\end{array}$ & $\begin{array}{c}\text { Emotionaal } \\
\text { Support and } \\
\text { Collaboration } \\
\text { Score }\end{array}$ & $\begin{array}{l}\text { Choir members' } \\
\text { Total Team } \\
\text { Perception Score }\end{array}$ \\
\hline Team Spirit Score & - & $\mathrm{r}=.634 * *$ & $\mathrm{r}=.391 * *$ & $\mathrm{r}=.636^{* *}$ & $\mathrm{r}=.569^{* *}$ & $\mathrm{r}=.858^{* *}$ \\
\hline $\begin{array}{l}\text { Choir and Conductor Relationship } \\
\text { Score }\end{array}$ & - & - & $\mathrm{r}=.375^{* *}$ & $\mathrm{r}=.552 * *$ & $\mathrm{r}=.554 * *$ & $\mathrm{r}=.826 * *$ \\
\hline Negative Emotions Score & - & - & - & $\mathrm{r}=.398 * *$ & $\mathrm{r}=.355^{* *}$ & $\mathrm{r}=.670^{* *}$ \\
\hline Responsibility and Effort Score & - & - & - & - & $\mathrm{r}=.600 * *$ & $\mathrm{r}=.771 * *$ \\
\hline $\begin{array}{l}\text { Emotional Support and Collaboration } \\
\text { Score }\end{array}$ & - & - & - & - & - & $\mathrm{r}=.737 * *$ \\
\hline $\begin{array}{l}\text { Choir members' } \\
\begin{array}{l}\text { Perception Score } \\
\text { Peral }\end{array}\end{array}$ & - & - & - & - & - & - \\
\hline
\end{tabular}

As a result of the Pearson Correlation Analysis conducted for the relationship between the total score averages and the subscale scores of the choir members, there was a significant correlation between the overall scale total score and the first sub-scale score, the overall scale total score and the second sub-scale score, the overall scale total score, and the third sub-scale score, the overall scale total score, and the fourth sub-scale score, the overall scale total score and the fifth sub-scale score at the level of $\mathrm{p}<.01$. 1st and 2nd sub-scales, 1st and 3rd sub-scales, 1st and 4th sub-scales, 1st and 5th sub-scales, 2nd and 3rd sub-scales, 2nd and 4th sub-scales, 2nd and 5th subscales, 3rd and 4th sub-scales, 3rd and 5 th sub-scales, and the 4th and 5th subscale scores were found to have a significant relationship at $\mathrm{p}<.01$ level.

The findings about the significant difference between choir members' team perception total scores and sub-scale scores in relation with gender, age, graduated school type variables is presented below.

Table 4. Independent samples t test results performed to determine whether the scale of choir team perception and subscale scores differ according to the gender variable

\begin{tabular}{|c|c|c|c|c|c|c|c|}
\hline & Gender & $\mathbf{n}$ & $\mathbf{x}$ & ss & sd & $\mathbf{t}$ & $\mathbf{p}$ \\
\hline \multirow{2}{*}{$\begin{array}{l}\text { Choir members' Total } \\
\text { Team Perception Score }\end{array}$} & Female & 155 & 116.26 & 12.43 & \multirow{12}{*}{244} & \multirow{2}{*}{2.923} & \multirow{2}{*}{$.004 * *$} \\
\hline & Male & 91 & 111.07 & 14.99 & & & \\
\hline \multirow{2}{*}{ Team Spirit Score } & Female & 155 & 35.72 & 4.47 & & \multirow[b]{2}{*}{1.922} & \multirow[b]{2}{*}{.056} \\
\hline & Male & 91 & 34.52 & 5.08 & & & \\
\hline \multirow{2}{*}{$\begin{array}{l}\text { Choir and Conductor } \\
\text { Relationship Score }\end{array}$} & Female & 155 & 31.97 & 4.00 & & \multirow{2}{*}{2.112} & \multirow{2}{*}{$.036^{*}$} \\
\hline & Male & 91 & 30.78 & 4.71 & & & \\
\hline \multirow{2}{*}{$\begin{array}{c}\text { Negative Emotions } \\
\text { Score }\end{array}$} & Female & 155 & 21.37 & 3.71 & & \multirow{2}{*}{2.884} & \multirow{2}{*}{$.004^{* *}$} \\
\hline & Male & 91 & 19.86 & 4.32 & & & \\
\hline \multirow{2}{*}{$\begin{array}{c}\text { Responsibility and } \\
\text { Effort }\end{array}$} & Female & 155 & 13.54 & 2.05 & & \multirow{2}{*}{2.195} & \multirow{2}{*}{$.029 *$} \\
\hline & Male & 91 & 12.91 & 2.36 & & & \\
\hline \multirow{2}{*}{$\begin{array}{c}\text { Emotional Support } \\
\text { and Collaboration } \\
\text { Score }\end{array}$} & Female & 155 & 13.65 & 2.04 & & \multirow[b]{2}{*}{2.262} & \multirow[b]{2}{*}{$.025 *$} \\
\hline & Male & 91 & 12.98 & 2.49 & & & \\
\hline
\end{tabular}

As shown in Table 4, a high level of difference was found in favour of female choir members according to gender variable, between team perception total scores of choir members and negative emotion subscale scores. It can be said that the scores of Choir and Conductor Relationship, Responsibility and Effort, Emotional Support and Collaboration subscales have a significant difference in favour of female choir members according to gender variable. There was no statistically significant difference in the team spirit scores of the choir members in terms of gender variable. According to these results, it can be said that female choir members generally have higher team perception than male choir members. 
Table 5. Results of One-Way ANOVA to determine whether the choir team perception scale and subscale scores differ according to age variable

\begin{tabular}{|c|c|c|c|c|c|c|c|c|c|c|}
\hline & $\begin{array}{c}\text { Age } \\
\text { range }\end{array}$ & $\mathbf{n}$ & $\mathbf{x}$ & ss & $\begin{array}{c}\text { Source of } \\
\text { variance }\end{array}$ & $\begin{array}{l}\text { Sum of } \\
\text { squares }\end{array}$ & sd & $\begin{array}{l}\text { Mean of } \\
\text { Squares }\end{array}$ & $\mathbf{F}$ & $\mathbf{p}$ \\
\hline \multirow{3}{*}{$\begin{array}{c}\text { Choir members' Total Team } \\
\text { Perception Score }\end{array}$} & $14-17$ & 59 & 117.06 & 11.85 & $\begin{array}{l}\text { Between } \\
\text { groups }\end{array}$ & 1638.623 & 2 & 819.311 & \multirow{3}{*}{4.528} & \multirow{3}{*}{$.12 *$} \\
\hline & $18-21$ & 131 & 115.04 & 13.51 & In Groups & 43973.008 & 243 & 180.959 & & \\
\hline & $22+$ & 56 & 109.83 & 14.81 & Total & 45611.630 & 245 & & & \\
\hline \multirow{3}{*}{ Team Spirit Score } & $14-17$ & 59 & 35.84 & 4.80 & $\begin{array}{l}\text { Between } \\
\text { groups }\end{array}$ & 85.381 & 2 & 42.690 & \multirow{3}{*}{1.920} & \multirow{3}{*}{.149} \\
\hline & $18-21$ & 131 & 35.47 & 4.55 & In Groups & 5404.266 & 243 & 22.240 & & \\
\hline & $22+$ & 56 & 34.23 & 4.99 & Total & 5489.646 & 245 & & & \\
\hline \multirow{3}{*}{$\begin{array}{l}\text { Choir and Conductor } \\
\text { Relationship Score }\end{array}$} & $14-17$ & 59 & 32.06 & 4.22 & $\begin{array}{l}\text { Between } \\
\text { groups }\end{array}$ & 34.987 & 2 & 17.494 & \multirow{3}{*}{0.941} & \multirow{3}{*}{.392} \\
\hline & $18-21$ & 131 & 31.53 & 4.40 & In Groups & 4518.253 & 243 & 18.594 & & \\
\hline & $22+$ & 56 & 30.96 & 4.16 & Total & 4553.240 & 245 & & & \\
\hline \multirow{3}{*}{ Negative Emotions Score } & $14-17$ & 59 & 21.06 & 4.00 & $\begin{array}{l}\text { Between } \\
\text { groups }\end{array}$ & 77.367 & 2 & 38.683 & \multirow{3}{*}{2.431} & \multirow{3}{*}{.090} \\
\hline & $18-21$ & 131 & 21.14 & 3.86 & In Groups & 3867.402 & 243 & 15.915 & & \\
\hline & $22+$ & 56 & 19.78 & 4.24 & Total & 3944.768 & 245 & & & \\
\hline \multirow{3}{*}{ Responsibility and Effort } & $14-17$ & 59 & 14.16 & 1.55 & $\begin{array}{l}\text { Between } \\
\text { groups }\end{array}$ & 116.444 & 2 & 58.222 & \multirow{3}{*}{13.371} & \multirow{3}{*}{$.000 * *$} \\
\hline & $18-21$ & 131 & 13.40 & 2.11 & In Groups & 1058.077 & 243 & 4.354 & & \\
\hline & $22+$ & 56 & 12.17 & 2.46 & Total & 1174.520 & 245 & & & \\
\hline \multirow{3}{*}{$\begin{array}{l}\text { Emotional Support and } \\
\text { Collaboration Score }\end{array}$} & $14-17$ & 59 & 13.91 & 2.01 & $\begin{array}{l}\text { Between } \\
\text { groups }\end{array}$ & 45.826 & 2 & 22.913 & \multirow{3}{*}{4.720} & \multirow{3}{*}{$.010^{*}$} \\
\hline & $18-21$ & 131 & 13.48 & 2.16 & In Groups & 1179.523 & 243 & 4.854 & & \\
\hline & $22+$ & 56 & 12.67 & 2.45 & Total & 1225.350 & 245 & & & \\
\hline
\end{tabular}

$* \mathrm{p}<.05$

$* * \mathrm{p}<.01$

In Table 5 as a result of the One-Way ANOVA conducted to determine whether the team perception score and subscale scores differ according to age variable, the difference between the mean scores of the total score of team perception of age groups, Responsibility and Effort subscale score and Emotional Support and Cooperation subscale were statistically significant.

After this analysis, complementary post hoc analyses were performed to determine which groups cause the meaningful difference and to decide which post hoc multiple comparison technique should be used. The homogeneity of the group distributions was tested with the Levene's test and the distribution was found not to be homogeneous. In the cases where the distribution is not homogeneous, the analysis is continued with Tamhane's T2 technique. 
Table 6. The results of Tamhane's T2 test performed to determine which groups differed according to the age variable and the scale of the choir team perception

\begin{tabular}{|c|c|c|c|c|c|}
\hline & Groups (i) & Groups (j) & $\mathbf{X}(\mathbf{i}-\mathbf{j})$ & sh & $\mathbf{p}$ \\
\hline \multirow{6}{*}{$\begin{array}{l}\text { Choir members' } \\
\text { Total Team } \\
\text { Perception Score }\end{array}$} & \multirow{2}{*}{$14-17$} & $18-21$ & 2.0220 & 2.1091 & .632 \\
\hline & & $22+$ & 7.2285 & 2.5096 & $.017 *$ \\
\hline & \multirow[b]{2}{*}{$18-21$} & $14-17$ & -2.0220 & 2.1091 & .632 \\
\hline & & $22+$ & 5.2065 & 2.1477 & .055 \\
\hline & \multirow{2}{*}{$22+$} & $14-17$ & -7.2285 & 2.5096 & $.017^{*}$ \\
\hline & & $18-21$ & -5.2065 & 2.1477 & .055 \\
\hline \multirow{7}{*}{ Team Spirit Score } & \multirow{2}{*}{$14-17$} & $18-21$ & 0.5334 & 0.6760 & .733 \\
\hline & & $22+$ & 1.1035 & 0.8044 & .392 \\
\hline & \multirow{2}{*}{$18-21$} & $14-17$ & -0.5334 & 0.6760 & .733 \\
\hline & & $22+$ & 0.5700 & 0.6884 & .710 \\
\hline & \multirow{2}{*}{$22+$} & $14-17$ & -1.1035 & 0.8044 & .392 \\
\hline & & $18-21$ & -0.5700 & 0.6884 & .710 \\
\hline & \multirow{2}{*}{$14-17$} & $18-21$ & 0.3741 & 0.7394 & .880 \\
\hline \multirow{5}{*}{$\begin{array}{c}\text { Choir and } \\
\text { Conductor } \\
\text { Relationship Score }\end{array}$} & & $22+$ & 1.6153 & 0.8798 & .188 \\
\hline & \multirow{2}{*}{$18-21$} & $14-17$ & -0.3741 & 0.7394 & .880 \\
\hline & & $22+$ & 1.2411 & 0.7529 & .259 \\
\hline & \multirow{2}{*}{$22+$} & $14-17$ & -1.6153 & 0.8798 & .188 \\
\hline & & $18-21$ & -1.2411 & 0.7529 & .259 \\
\hline \multirow{4}{*}{$\begin{array}{c}\text { Negative Emotions } \\
\text { Score }\end{array}$} & \multirow{2}{*}{$14-17$} & $18-21$ & -0.0772 & 0.6254 & .992 \\
\hline & & $22+$ & 1.2820 & 0.7442 & .229 \\
\hline & \multirow{2}{*}{$18-21$} & $14-17$ & -0.0772 & 0.6254 & .992 \\
\hline & & $22+$ & 1.3593 & 0.6369 & .105 \\
\hline \multirow{8}{*}{$\begin{array}{c}\text { Responsibility and } \\
\text { Effort }\end{array}$} & \multirow{2}{*}{$22+$} & $14-17$ & -1.2820 & 0.7442 & .229 \\
\hline & & $18-21$ & -1.3593 & 0.6369 & .105 \\
\hline & \multirow{2}{*}{$14-17$} & $18-21$ & 0.7649 & 0.3271 & .067 \\
\hline & & $22+$ & 1.9909 & 0.3893 & $.000^{* *}$ \\
\hline & \multirow{2}{*}{$18-21$} & $14-17$ & -0.7649 & 0.3271 & .067 \\
\hline & & $22+$ & 1.2260 & 0.3331 & $.001 * *$ \\
\hline & \multirow{2}{*}{$22+$} & $14-17$ & -1.9909 & 0.3893 & $.000^{* *}$ \\
\hline & & $18-21$ & -1.2260 & 0.3331 & $.001^{* *}$ \\
\hline \multirow{6}{*}{$\begin{array}{l}\text { Emotional } \\
\text { Support and } \\
\text { Collaboration } \\
\text { Score }\end{array}$} & \multirow{2}{*}{$14-17$} & $18-21$ & 0.4267 & 0.3454 & .467 \\
\hline & & $22+$ & 1.2366 & 0.4110 & $.012 *$ \\
\hline & \multirow{2}{*}{$18-21$} & $14-17$ & -0.4267 & 0.3454 & .467 \\
\hline & & $22+$ & 0.8099 & 0.3517 & .073 \\
\hline & \multirow{2}{*}{$22+$} & $14-17$ & -1.2366 & 0.4110 & $.012 *$ \\
\hline & & $18-21$ & -0.8099 & 0.3517 & .073 \\
\hline
\end{tabular}

$* \mathrm{p}<.05$

$* *$ p $<.01$

As a result of the Tamhane's T2 test, conducted in order to determine whether choir members' team perception total scores and sub-scale scores make a difference according to the age groups, a significant difference in $\mathrm{p}<.05$ level between the age groups 14-17 and 22 years and older, in favour of 22 years and older detected. A significant difference was found between 14-17 years age group and 22 years and older age group and between 18-21 years age group and 22 years and older group, in favour of the age group 22 years and above. A significant difference in $p<.05$ level was found in the subscale scores of Emotional Support and Collaboration, in favour of the 22 years and older age group. According to these results, it can be said that the chorus members who are 22 years of age and older have higher choir team perception than the choir members in the age group of 14-17 and 18-21 age groups. No significant difference was found between the scores of Team Spirit, Choir and Conductor Relationship and Negative Emotions subscales. 
Table 7. Independent samples t test results performed to determine whether the scale of choir team perception and subscale scores differ according to the type of graduated school

\begin{tabular}{|c|c|c|c|c|c|c|c|}
\hline & $\begin{array}{c}\begin{array}{c}\text { Type of graduated } \\
\text { school }\end{array} \\
\end{array}$ & $\mathbf{n}$ & $\mathbf{x}$ & ss & sd & $\mathbf{t}$ & $\mathbf{P}$ \\
\hline \multirow{2}{*}{$\begin{array}{l}\text { Choir members' Total } \\
\text { Team Perception Score }\end{array}$} & Music Field & 89 & 114.70 & 12.60 & & \multirow{2}{*}{.313} & \multirow{2}{*}{.755} \\
\hline & Non-music related & 157 & 114.14 & 14.23 & & & \\
\hline \multirow{2}{*}{ Team Spirit Score } & Music Field & 89 & 35.59 & 4.19 & & \multirow{2}{*}{.785} & \multirow{2}{*}{.433} \\
\hline & Non-music related & 157 & 35.10 & 5.01 & & & \\
\hline \multirow{2}{*}{$\begin{array}{l}\text { Choir and Conductor } \\
\text { Relationship Score }\end{array}$} & Music Field & 89 & 31.61 & 4.25 & & \multirow{2}{*}{.234} & \multirow{2}{*}{.815} \\
\hline & Non-music related & 157 & 31.48 & 4.35 & & & \\
\hline \multirow{2}{*}{$\begin{array}{l}\text { Negative Emotions } \\
\text { Score }\end{array}$} & Music Field & 89 & 20.91 & 4.04 & 244 & \multirow[b]{2}{*}{.273} & \multirow[b]{2}{*}{.785} \\
\hline & Non-music related & 157 & 20.76 & 4.00 & & & \\
\hline \multirow{2}{*}{$\begin{array}{l}\text { Responsibility and } \\
\text { Effort Score }\end{array}$} & Music Field & 89 & 13.07 & 2.11 & & \multirow{2}{*}{-1.243} & \multirow{2}{*}{.215} \\
\hline & Non-music related & 157 & 13.43 & 2.22 & & & \\
\hline \multirow{2}{*}{$\begin{array}{c}\text { Emotional Support } \\
\text { and Collaboration } \\
\text { Score }\end{array}$} & Music Field & 89 & 13.50 & 2.17 & & \multirow{2}{*}{.523} & \multirow{2}{*}{.602} \\
\hline & Non-music related & 157 & 13.35 & 2.27 & & & \\
\hline
\end{tabular}

As a result of the independent samples t test conducted to determine whether the team perception scores and subscale scores of the choir members differ according to the type of graduated school, there was no significant difference between the team perception total scores and the subscale scores of the choir members.

Table 8. Independent samples t test results performed to determine whether the choir team perception scale and subscale scores differ according to the choir experience variable

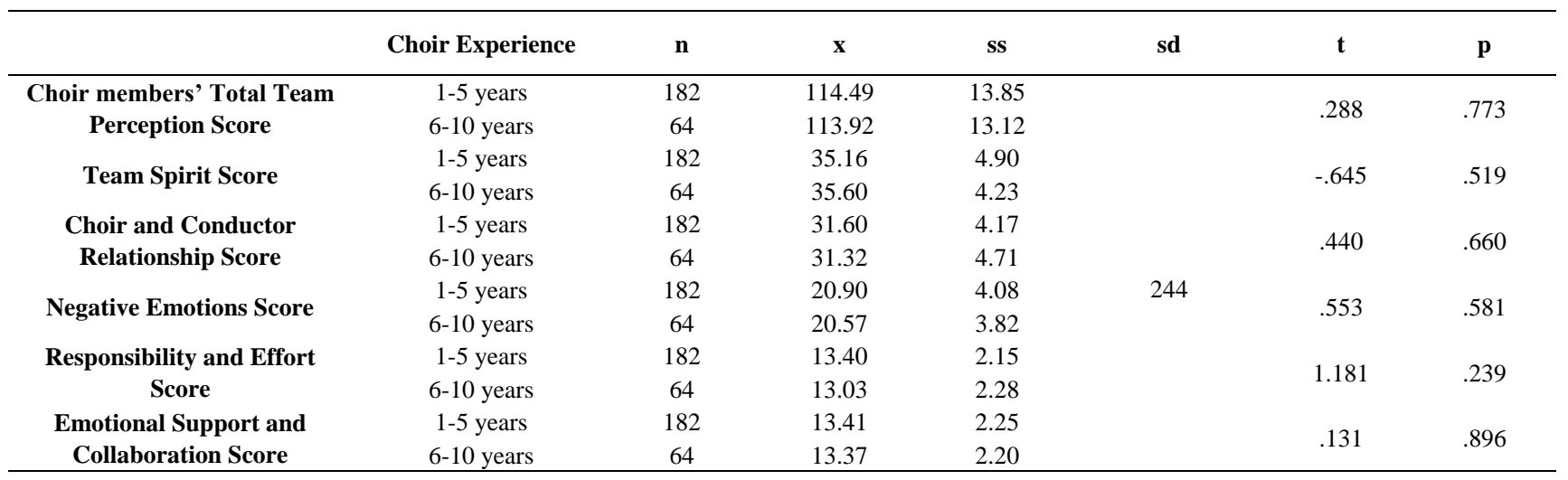

As shown in Table 8, as a result of the independent samples t test conducted to determine whether the team perception scores and subscale scores of the choir members differ according to the choir experience variable, team perception scores and subscale scores of the choir members did not make a significant difference.

\section{Conclusion}

In this study, the levels of the choir members' team perceptions and their sub-dimensions were discussed in terms of gender, age, type of graduated school and choir experience variables, and the results obtained were discussed.

As a result of the findings of the study, it was found that the choir members generally had a high level of team perception. The average score of the choir members in the team spirit, choir and conductor relationship, negative emotions, responsibility and effort, emotional support and collaboration sub-dimensions, shows a high level of team perception. Choir members need to have the sense of taking responsibility, sharing, feeling and concentration as they have in social life. In the choir, the atmosphere which takes its essence from the love of music and its inner discipline should be created (Çevik, 1997).

The most important behaviours required for a choir to be a high performance team are; shared purpose, mutual respect, trust, communication and understanding between members, appropriate studying methods, appropriate leadership, creating a regular study environment, providing and supporting individual development, establishing relations with other choir members, celebrating success and friendship (Sevinç, 2017). Within the framework of these considerations, the results of the research show that the members of the choir co-exist with the consciousness of being a team in such dimensions as togetherness, responsibility, sharing, effort, support and motivation. Choir members have high team perceptions and meet the expectations. 
There was a high and positive relationship between the total score averages of the choir members and all the subscale scores. In addition, as a result of the analysis of the subscales between each other, high level and positive relations were found.

According to the gender variable, a high level of difference was found in favour of female choir members among the total scores and the negative emotions subscale scores. It can be said that Choir and Conductor Relationship, Responsibility and Effort, Emotional Support and Collaboration subscale scores have a significant difference in favour of female choir members according to gender variable. There was no statistically significant difference in the team spirit scores of the choir members. According to these results, it can be said that female choir members generally have higher team perception than male choir members.

Demirtaş (2005), in his study on the team perception of the school staff, stated that the opinions of the administrators and teachers about whether they perceived their schools as a teaching team did not show a significant difference according to the gender variable and the opinions of female and male teachers about whether they perceive their schools as a teaching team are similar. Özgül (2013) in his study on student perceptions about effective motivational strategies in choir education, found that choir students' perception levels of effective motivation strategies (leadership, choir conductor/student attention, achievement and anxiety dimensions) did not differ in terms of gender. On the other hand, Ayanoğlu and Hamedoğlu (2013) found that the team perceptions of female teachers were higher than the male teachers in a study conducted to find out elementary school teachers' team perceptions. In this study, a high level of difference was found in favour of female choir members among the overall team perception and four sub-dimension scores of the choir members. The findings are in contradiction with the studies of Demirtaş (2005) and Özgül (2013) and are in line with the results of Ayanoğlu and Hamedoğlu (2013).

In the present study, the results of the age variable showed that there were significant differences between the mean score of Team Perception total score, Responsibility and Effort subscale score and Emotional Support and Collaboration subscale mean scores. According to this, a significant difference was found between the 14-17 age group and the 22 and older age group in favour of the 22 and older age group. There is a statistically significant difference between the 14-17 age group and the 22 and older age group and between the 18-21 age group and the 22 and older age group in favour of the 22 and older. In Emotional Support and Collaboration subscale score, a statistically significant difference was found between 14-17 age group and 22 and older age group in favour of the 22 and older age group. According to these results, choir members aged 22 years and older have higher choir team perception than choir members aged 14-17 years and 18-21 years. The difference between the scores of Team Spirit, Choir and Conductor Relationship and Negative Emotions subscales were not found to be statistically significant. Based on the findings, it can be assumed that the choir team perceptions increased with older age, achievements and experiences of the choir members.

There was no significant difference between the total score of the team perception and the subscale scores according to the school type variable of the choir members. According to the results, there is no significant difference between the team perceptions of the choir members who graduated from the music field and of the choir members who graduated from a different field. According to the results of Özgül (2013), no significant difference was found regarding the perception of motivation strategies about the "leadership, choir conductor/student attention, anxiety" dimensions of the choir students, between the fine arts high school graduates and general high school graduates. The results of his study support the findings of the present study.

The findings show that the team perception scores of the choir members and the subscale scores do not differ according to the choir experience variable. There was no significant difference between the team perception of the choir members who have choir experience between 1-5 years and the choir members who have choir experience between 6-10 years. According to this result, it can be said that the choir experiences of choir members did not make any difference on team perceptions. However, choir members with more experience in the choir were expected to have a higher team perception than choir members with less experience. In Demirtaş's (2005) research, team perceptions of teachers who work in the same school for a longer time was found to be higher than the teachers who work for shorter time. Also in the study of Ayanoğlu and Hamedoğlu (2013), it was determined that the teachers working in their schools for a longer time had a higher team perception. The results of these studies are in conflict with the findings of the present study. In this case, it can be said that with the effect of the unifying power of music, the choir members see themselves as part of a team in the same line and level, regardless of the duration of their choral life.

Based on the results obtained in this study, it is thought that new researches can be done to determine the relationship between the dimensions that are thought to be influential on the team perception of the choir members such as democratic attitude, emotional intelligence, motivation, and team perception. Teamwork based learning techniques can be applied to enable the choir members to act with team consciousness in their studies and performance. 
Concerning the conclusion that the choir members' team perceptions increase in line with their ages, successes and choral experiences, some innovative techniques can be applied in order to make the younger members of the choir to participate the studies willingly and not perceive the choir as a community limited to singing only. It can be suggested that the choir conductor and the experienced members of the choir should lead the new members in terms of supporting, helping, sharing and providing motivation.

\section{References}

Apaydın, M. (2006). The importance of child and youth choirs in the cultural development of society. Paper presented at the 2nd National Children and Youth Literature Symposium, Ankara. Retrieved from http://www.muzikegitimcileri.net

Ayanoğlu, Ç. and Hamedoğlu, M.A. (2013). Team perception of the teachers in the primary schools. Sakarya University Journal of Education, 3(1), 54-62.

Baltaş, A. (2004). Enriching teamwork. İstanbul: Remzi Kitabevi.

Büyüköztürk, Ş. (2004). Manual of data analysis for social sciences. Ankara: PegemA yayıncılık.

Çevik, S. (1997). Choir training and management techniques. Ankara: Doruk Yayımcılık.

Çevik, S. (1999). Choir training and management techniques. Ankara: Yurtrenkleri Yayınevi.

Demirtaş, H. (2005). Team perception of school employees. Ege Eğitim Dergisi, 6(1), 39-59.

Erol, I. (2013). Examination of the effect of children's choirs on school success of children. Yayınlanmamış Yüksek Lisans Tezi, Afyon Kocatepe Üniversitesi, Sosyal Bilimler Enstitüsü, Afyonkarahisar.

Ersoydan, M. Y., \& Karakelle, S. (2014). Investigation of transformational and transactional leadership behaviors choirmasters in Turkey. Süleyman Demirel Üniversitesi Güzel Sanatlar Fakültesi Dergisi, 13, 31-52.

Gökçe, M. (2007). An overall assessment of Turkey Choirs Festival. Paper presented at the 38th International Conference on Asian and North African Studies (ICANAS'38). Atatürk Kültür, Dil ve Tarih Yüksek Kurumu Başkanlığı, Ankara.

Güçlü, N., \& Okçu, V. (2015). The relationship between teachers' perceptions of effective team work and their organizational commitment. Yüzüncü Yıl Üniversitesi Eğitim Fakültesi Dergisi, 12(1), 49-69.

Halvaşi, B. (2016). Qualities of the choir conductor and basic approaches in choir management. International Journal of Innovative Research in Education, 3(4), 158-166. https://doi.org/10.18844/ijire.v3i4.1268

İlhan, A., \& İnce, E. (2015). Measurement of factors that determine team work and team efficiency: An Application at Gaziantep University. Kahramanmaraş Sütçü Imam Üniversitesi İktisadi ve İdari Bilimler Fakültesi Dergisi, 5(1), $127-152$.

Karasar, N. (1995). Scientific research method. Ankara: 3A Araştırma Eğitim Danışmanlık Ltd.

Katzenbach, J. R., \& Smith, D. K. (1998). The wisdom of teams and creating highly organized teams, İstanbul: Epsilon Yayınevi.

Özgül, İ. (2013). Student perceptions of effective motivational strategies in choral training. Yaynlanmamış Doktora Tezi, Necmettin Erbakan Üniversitesi, Eğitim Bilimleri Enstitüsü, Konya.

Punch, K. P. (2005). Introduction to social research. Ankara: Siyasal Kitabevi.

Sevinç, S. (2017). The importance of team-based learning in choir education. Fine Arts (NWSAFA), 12(4), 228-234.

Uçan, A. (2001). Foundations of human, music, choir and choir education. Paper presented at the 1. National Choral Training and Management Symposium, Ankara. Retrieved from www.muzikegitimcileri.net

Yiğit, N. (2001). Music teacher's chorus training needs and problems encountered, Paper presented at the 1. National Choral Training and Management Symposium, Ankara.

\section{Copyrights}

Copyright for this article is retained by the author(s), with first publication rights granted to the journal.

This is an open-access article distributed under the terms and conditions of the Creative Commons Attribution license which permits unrestricted use, distribution, and reproduction in any medium, provided the original work is properly cited. 